\section{$0-125$ w}

1 静岡市立静岡病院 呼吸器外科, ${ }^{2}$ 松江赤十字病院 呼吸器科

中島 大輔 ${ }^{1}$, 山科 明彦 ${ }^{1}$, 磯和 理貴 $^{2}$, 千原 幸司 ${ }^{1}$

目的：高齢者の気胸に対する手術の意義と安全性を検討する対象と方 法: 1995 年 6 月から 2003 年 10 月までに, 気胸に対する手術を行なっ た 80 歳から 87 歳 (平均 83 歳) の 15 例を対象とし, 基礎疾患, 術前 後の胸腔ドレナージ期間, 手術手技, 手術危険度, 術後合併症, 在院 期間を検討した。結果: 気胸は肺気腫 (14 例), 間質性肺炎 (1 例)に 続発するものであった．併存疾患は虚血性心疾患を 4 例，慢性腎不全， 肺結核症, 非定型抗酸菌症を各 1 例認めた。手術適応の内訳は 1) 初 回気胸だが気㾇持続が 10 例（平均術前胸腔ドレナージ期間は $14 \pm 6$ 日, 2 例に胸膜瘉着術施行歴), 2) 2 回目以上の気胸が 5 例でうち 3 例 で胸腔ドレナージ施行. 全体の平均術前胸腔ドレナージ期間は $14 \pm 7$ 日であった、術式は癒着剥離と気㾞部位特定を考慮して小開胸で行っ たのが 7 例, VATSが 5 例, VATS から小開胸に移行したのが 2 例, 再 側気腫肺減量術もかね胸骨正中切開が 1 例であった。肺瘦遷延にて 31 日間の術後胸腔ドレナージ＼cjkstart胸膜癒着療法を行なった 1 例を除くと, 平均術後胸腔ドレナージ期間は $7 \pm 3$ 日であった。術死 1 例（術後 10 病日：急性呼吸不全）で在院死 2 例であり, 死因は非定型抗酸菌症に よる慢性呼吸不全（術後 67 病日）と肺気腫による慢性呼吸不全（術後 1 年 3 ケ月) であった。術死, 在院死を除く平均術後在院期間は $15 \pm$ 8 日 (VATS： $10 \pm 4$ 日, 非 VATS：19 \pm 9 日, $p=0.023$ ). 再発は VATS で行った 1 例で術後 18 病日に認め, ドレナージで治癒した。結 語：80 歳以上の高龄者の気胸に, VATSのみならず小開胸でも術後在 院期間は 3 週間未満であり, 重篤な合併疾患を認める例では在院死の 危険があるものの, 術死, 術後合併症は少なく気胸根治をもたらす。

\section{$0-127$}

肺動静脈瘻の 2 症例一治療方針の検討一

\begin{abstract}
1 独立行政法人国立病院機構 三重中央医療センター 呼吸器外科, 2 独立行政法人国立病院機構 三重中央医療センター 心臓血管外科
\end{abstract}

渡邊 文亮 ${ }^{1}$, 金田 正德 ${ }^{1}$, 湯浅 右人 ${ }^{2}$, 谷 一浩 ${ }^{2}$, 森本 保 ${ }^{2}$, 坂井 隆 ${ }^{1}$

肺動静脈瘻 (PAVF) は胎生期の毛細血管形成不全による先天性疾患 と考えられており，肺動脈と肺静脈の異常短絡を来す血管奇形である. 近年 PAVF は良性疾患の位置づけにより，より低侵襲な加療が望まれ ている.外科手術に拀いては胸腔鏡下手術が多用され，またInterventional Radiology の進歩に伴い, 経皮的塞栓術の有用性が報告され ている，今回経皮的塞栓術と胸腔鏡下手術により加療した 2 症例を経 験したので若干の文献的考察を加え報告する。症例 1 は 44 歳の女性. 造影 CT 並びに血管造影検査で右肺動脈 $\mathrm{A}^{8}$ からの分枝における PAVF と診断された。流入動静脈の径は $3 \mathrm{~mm}$ で単一の血管からなっており, 経皮的塞栓術を施行した．塞栓物質としてはプラチナコイルを用い， 径 3-5mm1 個, 径 3-4mm2 個で塞栓術を施行した。手技終了值後より 意識レベルの低下を認めたため拡散強調 MRI を撮影したところ左前 頭葉に急性期の脳梗塞病変を認めた。保存的加療により軽快したが高 次機能障害は残存した。症例 2 は 73 歳の女性. 造影 CT並びに血管造 影検査で右肺動脈 $\mathrm{A}^{8}$ からの分枝におけるPAVF と診断され，胸腔鏡下 肺部分切除を施行した。縫合には自動切除縫合器 (Endo-GIA) を使用 した，術後経過良好でPOD\#10に退院となっている．疫学的に稀とさ れているPAVFだが今日の画像診断技術の進歩により今後症例数が増 えてくると思われる. 小型例に対しての治療方針に関しては経皮的塞 栓術が第一選択となりつつあるが，合併症の頻度を $3 \%$ 前後とする報 告もあり決して低くない. 最近の胸腔鏡下手術の進歩もあり外科的加 療も選択肢の一つとして入れるべきと考えた。

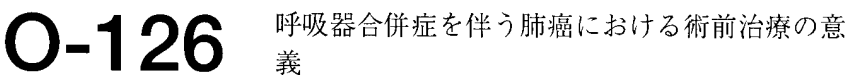

九州大学大学院 第二外科

小副川 敦, 吉野一郎, 山口 正史, 亀山 敏文, 米谷 卓郎, 饒平名 知史, 川野 大悟, 前原 喜彦

【背景】肺癌において, 呼吸器合併症, 特に慢性閉塞性肺疾患を伴う ものは10-30\%に上ると報告されており，このことは切除率を低下さ せる原因となっている。 今回, 呼吸器内科で短期間の内科的治療を 行った後，標準手術を試みた肺癌症例について検討した。【対象と方 法】 2000 年 4 月より 2004 年 10 月の間, 術前に呼吸器内科入院後, 当 科で手術を行われた, 呼吸器合併症を伴う症例 7 例 (肺気腫 3 例, 気 管支喘息 2 例，間質性肺炎 1 例，COPD1 例，うち 1 例は術前化学療 法を施行した症例）を対象とした。これらについて，術前治療前後の 呼吸機能検査, 予測残存一秒量の変化, 術後合併症の有無といった因 子について後向きに検討し, 解析を行った.【結果】術前治療を行われ たのは 7 例中 5 例であり，禁煙指導， $\beta$ 刺激剤吸入，抗コリン剂，キ サンチン内服が行われた。術前治療における入院日数は22-131 (平均 48）日で，一秒量の改善率は 4-37（平均 20）\%であった。そのうち 1 例に拧いては術前予測残存一秒量が $563 \mathrm{ml} / \mathrm{m}^{2}$ より $690 \mathrm{ml} / \mathrm{m}^{2}$ に改善 し，耐術可能となった。また，禁煙できず術前治療を行えなかった 2 例においては，消極的縮小手術を余儀なくされた．合併症としては， 術後肺炎 2 例，喘息発作 1 例，遷延性気漏 1 例が認められたが，致死 的合併症はなく, 術後入院期間は当科全症例で 12 日に対し，11-29(平 均 18.6) 日であった。【考察】呼吸器合併症を伴う肺癌においては, 呼吸器内科と協同して積極的に術前治療を行い, 完全切除率を向上さ せる必要があると考えられた。

\section{$0-128$ athase 例 18 例の検討}

\section{宝塚市立病院 呼吸器外科}

内海 朝喜, 明石 章則, 舟木 壮一郎

【目的】癌性胸膜炎に対しする胸腔内温熱化学療法 (HC) の安全性, 有用性について検討し, 原発性肺癌に対する治療戦略としての二期的 $\lceil\mathrm{HC} \rightarrow$ 胸膜肺全摘」の可能性を検討した。【対象・方法】2000年 1 月 から 2004 年 11 月の間の片側癌性胸膜炎を伴なった原発性肺癌 13 例 （腺癌 11 例，大細胞癌 1 例，扁平上皮癌 1 例）と転移性肺腫瘍 5 例 (大腸癌 3 例, 卵巣癌, 乳癌各 1 例)。年齢 22-80 歳 (平均 61.6), 男 10 例，女 8 例，右 7 例，左 11 例。全身麻酔にて胸腔鏡下に送水管と 排水管を胸腔内に留置し，人工心肺用の回路を用いて，胸腔温 $41-42^{\circ} \mathrm{C}$ で還流し，送排水が安定した時点でシスプラチン $200 \mathrm{mg} / \mathrm{m}^{2}$ を回路内 に加え，120 分または 60 分還流を続けた。還流終了後, 残った還流液 を可及的に吸引してドレーンを留置した。【結果】術前 $\mathrm{Cor}<$ $50 \mathrm{ml} / \mathrm{min}$ の 2 例で抗癌剂にカルボプラチンを使った。1例で血圧低下 により HCを 45 分で中止した，治療後に腎障害（Cr > 1.5）が 4 例 に見られた。原発性肺癌症例の5例でHC後28-34 日の間隔を置いて胸 膜肺全摘術を施行した。1 例を間質性肺炎で術後 34 日目に失い，1例 は術後 9 ヶ月に原病死, 3 例生存 (最長 45 ヶ月). $\mathrm{HC}$ 後の 3 年生存率 は全体で $38.5 \%$, 原発性肺癌症例で $43.2 \%$ (胸膜肺全摘術施行例 $53.3 \%$, 非施行例 $29.5 \%, \mathrm{p}=0.50$, Logrank).【結論】HC は安全 に施行しうるが，術後の管理上，急性腎障害に注意する必要がある。 片側癌性胸膜炎を伴なった原発性肺癌に対し「HC $\rightarrow$ 胸膜肺全摘」は， $\mathrm{HC}$ のみ場合に比べて, 生命予後の改善に寄与する可能性がある。 